\title{
Ups and Downs in Foreign Policy of Uzbekistan towards Security Approach of Russia*
}

\author{
Tugce Varol Sevim \\ Moscow State University, Russia \\ Alexander Rozanov \\ Moscow State University, Russia
}

\section{Introduction}

The strategic importance of Central Asia not only relies on the prospering wealth of the region but is also determined from theperspective of regional and international security. The newly independent countries of Central Asia, including Uzbekistan found themselves at the beginning of the New World Order (Farkhod 2007). Undoubtedly, September 11 events triggered a turning point in the security politics of Central Asia. US military engagement with the Central Asian countries has accelerated fighting radical Islamist extremism in Afghanistan and has influenced the written and unwritten rules in the region.Another turning point seems to be the withdrawal of NATO troops from Afghanistan in 2014. Since the start of NATO operations in Afghanistan, there has been no radical change in terms of potential threats and this country posesincludingradical Islamic organizations, drug trafficking and separatism. For these reasons, Central Asian countries, Russia and China continue on preparing for the upcoming future. While AfghanistanUSrelations have an impact on Uzbek security policy and its reflections on Russian security policy approach, domestic dynamics and leadership traditions have also direct impact on the Uzbek foreign policy and security policy.

Uzbekistan is considereda double-landlocked countrythat is located in the heart of Central Asia. It borders Afghanistan, one of the most unstable countries in the world. Uzbek population is the highest ethnic group in the region and exceeds every Central Asian state including Afghanistan. Thus,Uzbekistan with its large population has more powerful militaryresourcesthanother central Asian nations. This fact has a direct influence on the country's security policy. Moreover, the relations with US, Russia, China, Iran and regional organizations had an impact on Uzbek foreign policy in the region since its independence.

Russia's presence in Central Asia (both in its past and present form)has always 
been and is still an important strategic factor for the regional countries. For this reason, it is important to understand the process of Russian foreign policy and security policy approach towards Central Asia, particularly after the rise of President Putin in 2000. Contemporary Russian foreign policy is highly dependent on Russian energy policy and Central Asia isinevitablepart of this strategy. Regarding to existing pipelines, resources and future projects, Uzbekistan is on Russian energy policy agenda due to its energy export oriented economy. Therefore, security of Uzbekistan, Uzbek membership in Russian-led regional organizations and NATO withdrawal in 2014 consist main priorities of Kremlin. Despite the ups and downs of Uzbek foreign policy and security policy, Kremlin maintain its connection with Uzbek leader whether he is close to US alignment or not. Particularly the internal crisis of Uzbekistan had accelerated the diplomatic relations between Russian and Uzbekistan several times. Conversely in 2012 Tashkent once again withdrew from CSTO and even blocked the passage of some military vehicles for SCO military exercise (Turkkazak 2013). It is tremendously important to understand why Tashkent keep distance to Russia in terms of Russian security policy for the upcoming security gap in the region.

\section{Uzbek Foreign Policy and Security Policy}

Since the dissolution of the Soviet Union, many foreign policy intellectuals have cogitated that Uzbekistan has a key role in the Central Asia geopolitics. For example, Mackinder referred to it in 1904 as a "geographical pivot" (Megoran 2004). Uzbekistan with almost 30 million people has the largest population in Central Asia. ${ }^{1}$ The population has increased over the past 60 years, from around 6 million in 1950 s to almost 30 million today. Furthermore, it is estimated that population of Uzbekistan will increase to 33 million by $2020 .^{2}$ As a doublelandlocked country, Uzbekistan shares contiguous border with Kazakhstan, Turkmenistan, Tajikistan and Kyrgyzstan, along with Afghanistan but no border with Russia and China (Megoran 2004). By estimation,thepopulation of Uzbekistan together with Uzbek minorities in the neighboring countries constitutes $45 \%$ of the population of Central Asia (Kurecic 2010). Moreover, Uzbek Diasporain Afghanistan, Saudi Arabia, Turkey and Iran deserves our attention (Kalra\&Saxena 2009). Fumagalli believes that although the presence of Uzbek communities in

\footnotetext{
${ }^{1}$ According to official statistics of Uzbekistan, population number reached to 29993 in 2013 . The State Committee of the Republic of Uzbekistan Statists, Demographic Information, http://www.stat.uz/en/demographic/ accessed 13 August 2013.

${ }^{2}$ World Population Review, Population of Uzbekistan 2013, http://worldpopulationreview.com/population-of-uzbekistan/ accessed 13 August 2013.
} 
neighboring countries is an influential tool for Tashkent, Uzbek foreign policy reveals restraint in playing the "Uzbek card" (Fumagalli 2007). Most probably, the reason is that in case of deportation from these countries, Uzbekistan is unwilling to welcome these groups. On the other hand Uzbekistan hosts the largest military power in the region and such a military strength certainlycreates a space for maneuvering its foreign and security policy to more independent and proactive areas (Megoran 2004). Since the independence of Uzbekistan, the country sent military support to pro-government faction for Tajik civil war, conducted an unauthorized operation in foreign territory and unilaterally demarcated and mined state borders (Fumagalli 2007, Efegil 2009). And after September 11, Uzbek military strength received a particular attention from US forces and it served the first US military entrance to the region.

The Uzbek constitution grants the president virtually limited powers regarding toforeign policy making. Uzbek President Kerimov consciously refers to "Amir Timur" and his diplomacy tradition as one of the pillars of the Uzbek foreign policy. By doing this President Kerimov establishes a direct connection with Timur and enhances his authority and prestige (Anceschi 2010). Anceshi (2010) divides the Uzbek foreign policy approaches into three phases. During the first period (19911999)Uzbekistan utilized a disentanglement strategy operating simultaneously at bilateral and multilateral levels. For instance, Uzbekistan joined to GU(U)AM in order to find an alternative to CIS which is considered as the Russian-led organization, strengthened relations with the West and, most importantly, was established its position of regional leadership. In the second phase, between 2000 and 2005, Uzbek foreign policy continued to pursue disengagement from Russia. Following the September $11^{\text {th }}$, the rapprochement of Uzbek-US relations was promptly spearheaded in the areas of military bases (Karshi-Khanabad Base). During the third phase, which is between 2005 and 2010, the re-rapprochement of Uzbek-Russia relations has begunas a result of the US critics of the Andijan events and the Color revolution, which took place in Russia's Near Abroad.

Nevertheless, thekey element of the Uzbek foreign policy since the independence is based on pursuing an independent foreign policy after all. This characteristic feature of the Uzbek foreign policy obviously accelerated after the establishment of close ties with the US. One of the factors behind this development was foreign assistance and loans of US government to Tashkent in terms of economic and military needs (Wilhelmsen\&Flikke 2011). Bohr (2004) argues that since 1991 Uzbekistan has consolidated its position as regional hegemon in order to replace Kremlin's dominant power in Central Asia, which became apparent after the September 11 events. Uzbek leader Kerimov who has ruled the country since 1990 believes that due to Uzbekistan's strategic importance and being the strongest 
nation in the region, it had a legitimate right to claim regional leadership. Thus according to Kerimov, Uzbekistan alone could serve for the stability of the region (Efegil 2009). One of Uzbek efforts to replace Moscow in the region was to establish ofCentral Asian Union by the initiative of Tashkent. The organization was created as the Central Asia Union in 1994 and then it was renamed as the Central Asian Economic Community in 1998. At the beginning of 2000's the organization was redesigned to strengthen military and political cooperation among Central Asian countries, which was perceived as an alternative to the Russian influence in the region (Kazantsev 2010).

Iran is another important actor concerning Central Asia and security issues in the region since the beginning of 1990s. Iran revealed as a candidate actor to fulfill the power gap in the region with Turkey and China. Both Russia and the U.S. tried to prevent expansion of Iranian influence in the region regarding toits economic, political and cultural ties. Therefore Russia chose to develop its relation with Tehran in order to control foreign trade and energy routes by making Iran depend on Russian arms and nuclear technology sales in return for a non-aggressive policy in Central Asia. AlternativelyWashington opposed all the actions of Iran towards Central Asia and hoping to cut the ties between the regions it also increased the international sanctions against Tehran (Blank 1995).

The NATO decision to leave Afghanistan in 2014 has triggered discussions on the future of Central Asian countries as well as Uzbekistan. Instability of Afghanistan always played an important role on domestic and international relations of Uzbekistan with its extremist Islamic community. Fazendeiro (2003) thinks that Uzbek foreign policy is regularly shifting through greater independence rather that developing regional cooperation as written in Uzbek official political doctrine Mustaqilik(independence). However, as Fazendeiro (2003) pointed out that Afghan and Uzbek economic relations has developed through the last decade. For instance, in 2009 total trade between Afghanistan and Uzbekistan rose to $\$ 877$ million thatwas quarter of Afghanistan's total foreign trade. At this point, Uzbekistan has to design a strategy for post-NATO period in Afghanistan whether to act unilaterally or multilaterally.

Although Uzbekistan is a secular state, it has been struggling with the Islamist groups since the foundation of the country that had deep roots in the regionmore than centuries. The Islamic Movement of Uzbekistan (IMU) and HizbutTahrir alIslami (HizbutTahrir) began to actively operate especially in the southern part of country where the Afghan border is. The IMU used Afghanistan as a base of operations into Uzbekistan and Kyrgyzstan at the beginning of 2000s when Taliban was in power in Afghanistan. Therefore, the U.S.hasenlisted IMU as a terrorist 
organization due to its connections with Taliban and al-Qaeda. On the other hand, while the U.S. was ignoring HizbutTahrir as a terrorist organization like IMU, Karimov claimed that HizbutTahrir initiated the Andijan event in 2005, which led toinstabilitywithinUzbekistan(Karagiannis 2006). ${ }^{3}$ The Uzbek political system is mainly characterized by clan politics. According to Starr, clans are the regional networks that exists in every country of Central Asia. Theyare based on close economic and political ties and accent. These regional networks are extremely powerful, reflecting the diverse emirates and local power centers of earlier centuries (Starr 2006). ${ }^{4}$ Karagiannis (2006) says that; "The clan-based nature of Uzbek politics has encouraged the establishment of patron-client relations, which create winners and losers, undermine the people's faith in meritocracy, and produce latent conflict in social relations." Furthermore, Markowitz (2012) considers Uzbekistan as a very controversial country due to its highly centralized decisionmaking, brutally repressive and autocratic structure. Thus, the regime is capable of high levels of control over society, politics, media, and economy, all of which requires significant state power.

Central Asia is a quite productive region in terms of having regional organizations, namely CIS (Common Independent States), Eurasec (Eurasian Economic Community), CU (Customs Union), SCO (Shanghai Cooperation Organization, ECO (Economic Cooperation Organization), CSTO (Common Security Treaty Organization) and finally Central Asian Cooperation Organization (CACO) (Tolipov 2007). ${ }^{5}$ Uzbekistan is currently a member of CIS (1994), Eurasec (2005), SCO (2001), ECO (1992), CACO (2004) but not a member of CSTO (joined 1994, withdrew 1999 and rejoined in 2006) since last year, GUAM since 2005 and never ever close to become a member of CU so far. In addition to these organizations Uzbekistan also signed a Partnership for Peace agreement with NATO in 1994 and President Karimov attended various summits of NATO in Europe. ${ }^{6}$

\section{Russian Foreign Policy and Security Policy Towards Central Asia}

Central Asia has always been a significant region since the establishment of the new Russian state. However, the rise of Putin to the Russian presidency is a turning

\footnotetext{
${ }^{3}$ CNN, Thousand of Uzbeks Fleeing, May 15, 2005, http://edition.cnn.com/2005/WORLD/asiapcf/05/14/uzbekistan/

${ }^{4}$ For more details Kathleen Collins, Clan Politics and Regime Transition in Central Asia, Cambridge University Press, 2006.

${ }^{5}$ The authors have added or brought out some organizations from the original text of the source.

${ }^{6}$ Ministry of the Foreign Affairs of The Republic of Uzbekistan, http://mfa.uz/eng/inter_cooper/intern_organiz/uzb_nato/ accessed on August 15, 2013.
} 
point in both Russian and Central Asian political history. In the first days of his Presidency, Vladimir Putin gave the signals of upcoming Russian foreign policy interests in his millennium article that was published at the end of 1999. The main theme of the article was to restore under a strong state; overcoming backwardness by establishing a market economy in Russia; and reviving a sense of nationhood in post-Soviet Russia (Gaddy\&Kuchins 2008). Afterwards the idea of 'Multipolarity' emerged among Kremlin decision-makers and they put this new argument into the Russian important document. Here Trenin (2003a) claims that Putin has abandoned Yeltsin's foreign policy agenda, with desire to play an oversized role in world affairs and a quest for multipolarity to balance America. The 9/11 attacks provided a further impetus for Putin to seek a pragmatic relationship with Washington, free for the most part from the overheated rhetoric and bluster that often characterized the Primakov/Yeltsin era. Putin was the first foreign leader (Dougherty 2002) contacted Bush in the hours following the attacks on New York and Washington (Mankoff 2006). Despite the opposition of the Russia's Security Council, Putin supported Washington's anti-terrorist campaign without preconditions and accepted the American deployment in Central Asia (Rywkin 2003). Blank (2008) summarized the concept of multipolarity as; "the entire concept of multipolarity implies a virtual veto over the unilateralist impulses of any great power: other powers align against any aggressive power in an effort to preserve the status quo and to ensure that any major challenges in the international system require consensus."

In the first months after Putin's election three key documents were adopted in 2000: the National Security Concept, the Military Doctrine and the Foreign Policy Concept. In the Foreign Policy document it was re-sealed that post-Soviet countries -Near Abroad- were as the main priority (Kazantsev 2008). When Russian Federation was recognized as the legal inheritor of the Soviet Union in UN and other international organizations, other former 14 states declared their sovereignty and they are known as Near Abroad states. Therefore Central Asian states also belong to the Russian Near Abroad concept because Russia has vital political and economic interests in the region. Furthermore, Russia is also concerned about the growth of Islamic fundamentalism in Central Asia and its possible spread to Russian Muslim communities (Donaldson \&Nogee 2009). Russia is worried about Taliban movement within Afghanistan and their activities in the republics of Central Asia (Yakushik 2009).

After the dissolution of the Soviet Union, the "Great Game" politics has become a subject for numerous discussions and disputes among scholars. Scholars tried to figure out whether the "New Great Game" will appear in Central Asia or not. The classic Great Game represents the power competition between the Russian Empire 
and Great Britain in the $19^{\text {th }}$ century over the hegemony of Central Asia, which was also the gateway to Afghanistan and India (Abilov 2012). However, many scholars argue that New Great Game is different than the old one. Tolipov says the New Great Game is multilevel, multinational and multifaceted, too many actors wereinvolved in the game and even Central Asian countries become players (Tolipov 2007). Abilov (2012) believethat The United States has taken over the leading role from the British. Along with the ever-present Russians, new regional powers such as China, Iran, Turkey and Pakistan have entered the new arena. Therefore after gaining their independence in 1991, five republics of the region faced multi-complex security issues, directly connected to foreign policy matters. Once again after a century "Great Game" raised and determined the agenda of the countries in the region. Just this time the question changed as Nourzhanov (2009) quotes to Starr: the region will either come under the hegemony of an outside rival power-Russia, China, the US- or the region will be in chaos.

The Russian economy is mainly dominated by energy export incomes that are also dependent to Central Asian resources either controlling supply routes orprovidingsurplus resources for exporting to West. Therefore, high oil prices and its direct impact on the increase of natural gas prices had served Russian development since 1999 (Hanson 2009). For Russian energy policy, Central Asian policy also includes the Caspian energy policy dynamics. For this reason, controlling the direction and volumes of exports from the states of this region is essential for Russia in order to reduce competition for its own energy exports on the international markets (Nanay 2009). In this sense, Energy policy began to play an important role in Uzbekistan after the independence. It was correlated with the capital-intensive industrialization policy and overall macroeconomic policy on domestic stabilization (Djakhangir 2005). Since the beginning of Putin's presidency, Uzbekistan gradually saw some progress in cooperation with Russia. In 2002, 10year contract was signed between Russia and Uzbekistan to supply gas to Russia including Russian investments into the hydrocarbon deposits. Afterwards, Russia and Uzbekistan signed a 15-year PSA with Gazprom on gas extraction at the Shokhpakhty gas fields, and Russia's Lukoil signed an agreement for 35 years to develop the Kandym gas field. Following the improvement in relations with Russia after the crackdown in Uzbekistan's Andijan (Cooley 2008) ${ }^{7}$ region in 2005, Gazprom announced future investments in Uzbek gas projects (Nygren 2008). On May 2005, Uzbekistan quit the GUUAM grouping which was generally viewed as

\footnotetext{
7 “...Andijan events: On Friday, 13 May 2005, thousands of demonstrators gathered around Babur Square in the centre of the city. Uzbek security forces dealt with the protesters ruthlessly, surrounding the demonstrators in armored vehicles and proceeding to fire into the crowd. The Uzbek government received unequivocal backing for its actions from Russia and China, but crack down in Andijan sent shock waves through the West."
} 
pro-Western.

In terms of regionalization strategy of Russia, it is significant to look at the various regional organizations in the region. Firstly, the Commonwealth of Independent States (CIS) is a regional organization formed by the majority of the Soviet Republics in December 1991. First the leaders of the Soviet Republics of Belarus and Ukraine met in Belarus where they signed an agreement to establish CIS. Afterwards, in December 21, 1991, the leaders of the other eleven Soviet republics met in Almaty, Kazakhstan, and signed the CIS Charter. As a result of this document, the USSR was resolved and it was stipulated that all signatory states of the charter were both sovereign and independent states. The main aims behind the formation of CIS were to provide aid for newly independent former Soviet republics in foreign and economic fields (Peimani 2009).

Secondly, the Collective Security Treaty was signed on May 15, 1992, by Armenia, Kazakhstan, Kyrgyzstan, Russia, Tajikistan, and Uzbekistan, in Tashkent as the first security document of the Central Asian states. Afterwards Azerbaijan, Georgia and Belarus also signed the treaty by the end of year 1993. The treaty confirmed the will of all participating states to abstain from the use of threat of force. The important point of the treaty was that signatory states would not be able to join other military alliances and an aggression against one signatory would be perceived as an aggression against all (Obydenkova2001) as inNATO Article 5. On October 7, 2002, the six members of the Collective Security Treaty signed a charter in Chisinau, Moldova while expanding the organization and renaming itselfto the Collective Security Treaty Organization (CSTO) (Obydenkova 2001). Since its formation in 2002, CSTO has served not only to train Central Asian officers in Russian military academies but has also been a framework for delivery of both Soviet-era and most modern military equipment to the Central Asian militaries at Russian internal prices (Frost 2009).

Thirdly, Shanghai Cooperation Organization (SCO) consists of Russia, China, Kazakhstan, Tajikistan, Kyrgyzstan and Uzbekistan. Although it was announced during the establishment process that the $\mathrm{SCO}$ is not a military alliance, the organization adopted priorities over fighting on terrorism, religious extremism and separatism in 2001. Moreover Regional Anti-terrorist Structure (RATS) was created in Tashkent a year later as a tool for security of the members (Tolipov 2007). In July 2002, SCO adopted a strategic declaration that in case of extraordinary situations -threatening peace, stability and security in the regionSCO members will immediately start contacting for joint operational reaction (Tolipov 2007). Aris suggests that SCO has adopted flexible definitions of Islamist extremism and terrorism. For this reason, when the Uzbek government came under 
heavy criticism due to its implementations during the Andijan events in 2005, Russia, China and other Central Asian republics did not join in the criticism of the Uzbek government (Airs 2009). After the Andijanevents Uzbekistan was increasingly under influence from China and Russia to join SCO. The final statement of the summer 2005 SCO summit directly demanded that non-regional powers eventually remove military bases stationed in member countries and called for a timeline for such withdrawal that directly targeted US military bases. As a result, on August 2005, Uzbek authorities requested the U.S. to vacate the base at Karshi-Khanabad within 180 days (Wilhelmsen\&Flikke 2011).

\section{Understanding New Approach of Tashkent Policy and Its Counterterrorism Aspects}

According to Muzalevsky (2009), Russia-Uzbek relations have never been stable. In 1998, Uzbekistan withdrew from CSTO and joined GU(U)AM (Georgia, Ukraine, Uzbekistan, Azerbaijan, and Moldova) which was considered Western oriented and anti-Russian alliance. After the September 11 events, Russia supported the American use of military bases in Central Asia and thus Uzbekistan established a direct contact with Washington by hosting a Karshi-Khanabad airbase for U.S. military use. The Karshi-Khanabad Air Base near the Uzbek-Afghan border, which came to be known as $\mathrm{K} 2$ by the Americans, served as an important bridgehead for projecting American force onto Afghanistan. However, five months after the Andijan events in 2005 Putin and Karimov signed a Treaty of Allied Relations that included the possibility of Russian military re-settlement into Uzbekistan. In a few months Uzbekistan joined Russian-led organizations such as Eurasian Economic Community and CSTO. In addition to these developmentsserious energy treaties havesigned between Russia and Uzbekistan (Nixey 2012). Nevertheless, Uzbekistan didn'twelcome Russian military presence on its own territory. Megoran suggests that Moscow had two political objectives that Uzbeks opposed: firstly, the Russian military presence would constrain Tashkent's development as a western-leaning potential geopolitical competitor in Central Asia, and, secondly, Uzbeks felt the need to have military options for possible intervention in Uzbekistan in the future (Megoran 2004).

In 2012 Uzbekistan withdrew from CSTO second time in its history. Laruelle argues that several reasons explain Tashkent's second withdrawn from CSTO. Firstly, Uzbekistan has always problems with the values of the CSTO and it hinders Uzbek's autonomous foreign policy approach. Secondly, Uzbekistan's goal is to free itself from Russian domination and it is becoming impossible as long as 
Tashkent stays in the alliance. Thirdly, Uzbekistan is willing to create its own regional hegemony by reviving Turkestan idea that is a part of Turanism and directly challenges the Eurasianist ideas of Kazakh President Nazarbayev (Lauelle 2012). Moreover, although Uzbek-U.S. relations are not at peak, acceptance of the Russian proposal that any new third country military deployments in the region require the unanimous support of all members-sates was against Uzbek security policy. Uzbekistan wants to keep a negotiation tool for U.S. always in its hand and it becomes impossible after this rule accepted by the CSTO. And finally, Russia and Uzbekistan were negotiating to finalize the establishment of a Collective Rapid Reaction Force which Tashkent was not interested (Laruelle 2012).

In human history, terrorism is widely recognized as the world most famous enemy of the humanity. We should not underestimate this threat: terrorism isequivalent to annihilation with far-reaching and destructive effects; it is the cruelest of crimes against humanity. Its remains have turned neighbors into enemies and have made our societies and the whole world unsafe for living. Its aims and applications are global and uncompromising (Micheal 2003). Neither terrorism nor perpetrators are newfacts. Socio-economic explanations of terrorism suggest that various forms of deprivation drive people to terrorism, or that people are more susceptible to recruitment by organizations using terrorist tactics.Definitely, terrorism with its destructive power has reshaped the world we live in. Now we live in the world characterized by increasing violence and conflicts. This, in turn, has led to the emergence of mistrust, fear, and division. And nowterrorismrepresents a significant new threat to international justice, peace and security.

The term 'terrorism' describes a particularly heinous methodology that is used to create or cause change within a society. It is a political tool directed at achieving a specific goal through the deliberate targeting of noncombatants. In other words, terrorism is an activity that engages groups and individuals - this term describes what they do, but not who they are. NowadaysUzbekistan is boosting its security measures and warning residents of an increased risk of a terrorist attack. Authorities have "credible information" that has prompted the precautionary efforts, especially in Tashkent. "In addition to the escalation of terrorist activity across the region and the world as a whole by groups that made a name with their previous terrorist acts in our country - the Islamic Movement of Uzbekistan (IMU) and Salafist groups - we now have information that terrorists are grouping on the border of Afghanistan, Tajikistan and Turkmenistan," National Security Service terrorism analyst said though he declined to discuss specifics about the available intelligence data for security reasons. "This poses a danger to Uzbekistan" (Sadi\& Khan 2013). 
IMU and al-Qaeda militants have reportedly been massing in Badakhshan Province, Afghanistan, which is closer to Tajikistan than to Uzbekistan but nonetheless, it is worrisome for the Uzbeks. The Afghan government wasted no time and quickly started working with Tajikistan to eliminate the problem. Din Muhammad, a senior politician, said "We are tackling the issue in collaboration with our neighbor and are controlling of [the militants'] activities," Din Muhammad said. "They have been sandwiched, and soon the region will be made clear" (Sadi\& Khan 2013). One challenge is that extremists have broadened their communication networks, using the Internet to spread their propaganda. The Internet is accessible and insufficiently regulated, has an unlimited potential readership, and allows a rapid flow of information. Groups that achieve their goals through terrorism have benefited from these inherent advantages of the Internet, and this is very hard to combat. Lt. Col. Anwar Salimov of the Interior Ministry, referring to a report by various law enforcement agencies, said that this situation made it easier for terrorists to collaborate across international borders.

Now Uzbekistan is more focused on what's happening with extremists on its own territory. Vehicles entering and leaving the capital will be checked and security has been boosted at strategically important buildings, in outdoor public areas like parks and on public transportation. The primary goal is to ensure the safety of Uzbeks, and, as a result, authorities will enhance security measures across the borders. The fight against terrorism is a common task for all countries in the world, it is a «collective» responsibility for the whole international community. Preventing terrorist threat will be successful only if the states abandon the policy of 'double standards' and interact with each other strictly in accordance with universal principles of international law.

In our opinion, possible measures against international terrorism could be the following:

1) To eliminate communication between various terrorist organizations and criminal groups operating on the territory of any state;

2) To shut down all sites and Internet resources that contains material of a terrorist nature and propaganda of extremist ideas;

3) To create a common international database on terrorism, which will serve as a tool for collecting and analyzing information on terrorist elements, groups, movements and organizations around the world;

4) To hold regular dialogue with the leading authoritative politicians, cultural and religious leaders to disseminate ideas to combat terrorism, explaining the terrorists' 
real objectives, thus creating in civilians' minds the image of the real enemy - the terrorism;

5) To formulate the so-called 'counter-terrorist ideology'.

\section{Conclusion}

The development of geopolitical processes over the past decadedemonstrated that Central Asia has become one of the key Eurasian regions, with major impact on the overall climate of the continental and global security. Central Asia's influence is felt on several fronts, primarily those of combating international terrorism and supplying oil and natural gas. At the same time, the region's growing importance carries certain risks. As the region becomes an integral part of the global system of security and the economy, it also becomes sensitive to the effects of the multiple factors and processes that traditionally determine the course of global political, economic, cultural, and ideological development. In this sense, as Ilkhamovpointed out, Uzbekistan is highly significant for Russian interests not only due to its energy resources, but also for its Geo-strategic location. Although Uzbekistan is a doublelandlocked country, it is situated in the 'heart' of the Central Asia including Russia, China, Afghanistan, Iran, and the Caspian Region (Ilkhamov 2007).

Uzbekistan is a unique case in Central Asia in terms of pursuing independent foreign policy. According to this strategy, Tashkent enjoys regional organizations although it has reservations. In 2012 Uzbekistan withdrew from the CSTO, which is the Russian-led security organization and has agreed on not allowing third party military bases in the region without unanimous agreement of the members. Afterwards, Uzbekistan blocked passage of Kazakh military vehicles for SCO military exercise in Tajikistan. This situation raised the questions whether Uzbekistan tries to recover its relations with the U.S. or not. It seems that Uzbekistan prefers the role of an observer in order to maintain its independent foreign policy as long as it can. Moreover, this does not mean the cut of economic or energy relations or a challenge for Russian security policy priorities. In sum, it gives Uzbekistan another diplomatic card for further negotiations with either Russia or the USA whether it is related to economics and security.

\section{References and notes:}

Abilov, S. (2012), “The 'New Great Game' Over the Caspian Region: Russia, the USA, and China in the Same Melting Pot", Khazar Journal of Humanities and Social Sciences, Volume: 15; Issue: 2, 29-60.

Akbarzadeh, S. (2007), “Uzbekistan and the United States: Friends or Foes?”,Middle East 
Policy, Vol.14, No.1, Spring, 107-116.

Anceschi, L. (2010), "Integrating Domestic Politics and Foreign Policy Making: The Cases of Turkmenistan and Uzbekistan", Central Asian Survey, Vol.29, No.2, June, 143158.

Aris, S. (2009), "The Shanghai Cooperation Organization: 'Tackling the Three Evils'. A Regional Response to Non-Traditional Security Challenges or an Anti-Western Bloc?",Europe-Asia Studies, Vol.61, No.3, May, 457-482.

Blank, S. (1995), "Russian Policy and Central Asian Energy, Economics, and Security", Demokratizatsiya, No.2, Spring, 187-208.

Blank, S. (2008), "Pax Americana in the Persian Gulf and the Contradictions of Russian Foreign Policy", in "Great Powers and Regional Orders: The United States and the Persian Gulf”, ed. Markus Kaim, Ashgate Publishing, 223-240.

Bohr, A. (2004), "Regionalism in Central Asia: New Geopolitics, Old Regional Order", International Affairs, 80, 3, 485-502.

CNN (2005), Thousand of Uzbeks Fleeing, May 15, http://edition.cnn.com/2005/WORLD/asiapcf/05/14/uzbekistan/

Collins, K. (2006), "Clan Politics and Regime Transition in Central Asia", Cambridge University Press, 2006.

Cooley, A. (2008), "Principles in the Pipeline: Managing Transatlantic Values and Interests in Central Asia", International Affairs, 84:6, 1173-1188.

Djakhangir, S. (2005), "Energy Policy, Economic Cooperation, and Sustainable Development in Central Asia: The Case of Uzbekistan", Dissertation in JustusLiebig University, 15 April,

http:/geb.uni-giessen.de/geb/volltexte/2005/2275/pdf/SagdullaevDjakhangir-2005-0713.pdf

Donaldson, R.H. \&Nogee, J.L. (2009), "The Foreign Policy of Russia, Changing Systems, Enduring Interests”, M.E.Sharpe.

Dougherty, J. (2002), “9/11 a 'Turning Point' for Putin”, CNN World, Foreign Policy, 10 September http://articles.cnn.com/2002-09-10/world/ar911.russia.putin_1_russianpresident-vladimir-putin-dmitri-trenin-moscow-carnegie-center?_s=PM: $\overline{\mathrm{W}}$ ORLD

Efegil, E. (2009), "Regime Security vs. Imperialist Geopolitics: Which Factors Dominate the Decision Makıng of the Central Asian States?", OAKA, 4 (8), 50-70.

Fazendeiro, B.T. (2003), "Uzbekistan's Afghan Interests and Its Foreign Policy After 2014?",Defence Academy of the United Kingdom, 12/3.

Frost, A. (2009), "The Collective Security Organization, the Shanghai Cooperation Organization, and Russia's Strategic Goals in Central Asia", China and Eurasia Forum Quarterly, 7(3): 83-102.

Fumagalli, M. (2007), "Ethnicity, State Formation and Foreign Policy: Uzbekistan and 'Uzbeks Abroad"', Central Asian Survey, March, 26(1), 105-122.

Gaddy, C.G. \&Kuchins, A.C. (2008), "Putin's Plan”, The Washington Quarterly, 31:2, 117 129.

Hanson, P. (2009), “The Sustainability of Russia's Energy Power”, in "Russian Energy Power and Foreign Relations", ed. JeronimPerovic, Robert W. Orttung and Andrreas Wenger, Routledge, 2009, 23-50.

Ilkhamov, A. (2007), "Russia Lures Uzbekistan as its Strategic Satellite in Central Asia", Robert Orttung, JeronimPerovic, HeikoPleines, and Hans-Henning Schröder ed., "Russia's Foreign Policy: Key Regions and Issues", ForschungsstelleOsteuropaan der Universität Bremen, 87, November, 31-34.

Kalra, F. \&Saxena, S.S. (2009), "Hidden Linkages: The Republic of Uzbekistan and the 
Gulf Region in a Changing World Order", in "Russian and CIS Relations with the Gulf Region: Current Trends in political and Economic Dynamics", ed. Marat Terterov, The Gulf Research Council.

Karagiannis, E., (2005) "Political Islam in Uzbekistan: HizbUt-Tahrir Al-Islami", EuropeAsia Studies, Vol.58, No.2, March, 261-280.

Kazantsev, A. (2008), "Russian Policy in Central Asia and the Caspian Sea Region", Europe-Asia Studies, 60:6, 1073-1088.

Kazantsev, A. (2010), "Russian Policy in Central Asia in 1991-2010: A Disappearing Power?", Robert Schuman Centre For Advanced Studies, EUI Working Papers, RSCAS 2010/59.

Kurecic, P. (2010), "The New Great Game: Rivalry of Geostrategies and Geoeconomies in Central Asia", HrvatskiGeografskiGlasnik, 72/1, 21-48.

Laruelle, M. (2012), "Factoring the Regional Impact of Uzbekistan's Withdrawal From the CSTO", GMF, August, http://www.gmfus.org/wpcontent/blogs.dir/1/files_mf/1345830436 Laruelle Uzbekistan Aug12.pdf

Mankoff, J. (2006), "Vladimir Putin and the Re-Emergence of Russian Foreign Policy", Yale University, International Security Studies Certificate Paper Series, Number 0602.

Markowitz, L.P. (2012), “The Sub-National Roots of Authoritarianism: Neopatrimonialism and Territorial Administration in Uzbekistan", Demokratizatsiya, Vol.20, No.4, Autumun, 387-408.

Megoran, N. (2004) "Revisiting the 'Pivot': The Influence of Halford Mackinder on Analysis of Uzbekistan's International Relations", The Geographical Journal, Vol.170, No.4,347-358.

Michael, G. (2003), "Confronting Right Wing Extremism and Terrorism in the USA", New York - London: Routledge.

Ministry of the Foreign Affairs of The Republic of Uzbekistan, (2013), http://mfa.uz/eng/inter_cooper/intern_organiz/uzb_nato/ accessed on August 15

Muzalevsky, R. (2009), "Russia's Strategy in Central Asia: An Analysis of Key Trends", Yale Journal of International Affairs, Winter, 26-42.

Nanay, J. (2009), "Russia's Role in the Eurasian Energy Market", in "Russian Energy Power and Foreign Relations", ed. JeronimPerovic, Robert W. Orttung and Andrreas Wenger, Routledge, 109-130.

Nixey, J. (2012) "The Long Goodbye: Waning Russian Influence in the South Caucasus and Central Asia", Chatham House, Briefing Paper, REP RSP BP 2012/03, June, p.8-12.

Nourzhanov, K. (2009) "Changing Security Threat Perceptions in Central Asia”, Australian Journal of International Affairs, Vol.63, No.1, March.

Nygren, B. (2008), "Putin's Use of Natural Gas to Reintegrate the CIS Region", Problem of Post-Communism, Bol.55, No.4, July/August, 3-15.

Obydenkova, A. (2001), "Comparative Regionalism: Eurasian Cooperation and European Integration, The Case For Neofunctionalism", Journal of Eurasian Studies, 2: 87102.

Peimani, H. (2009), "Conflict and Security in Central Asia and the Caucasus", ABC-CLIO.

Rywkin, M. (2003), "Russia and the Near Abroad Under Putin", American Foreign Policy Interests, 25, 3-12.

Sadi, S. \&Khan, H. (2013), "UzbekistanTightens Security Because of Terror Risk", Central Asia Online, 5 August 2013,

http://centralasiaonline.com/en_GB/articles/caii/features/main/2013/05/08/feature-01 
Starr, F, (2006), "Clans, Authoritarian Rulers, and Parliaments in Central Asia", Central Asia-Caucasus Institute \& Silk Road Studies Program, Silk Road Paper, June 2006.

The State Committee of the Republic of Uzbekistan Statists, Demographic Information, http://www.stat.uz/en/demographic/

Tolipov, F. (2007), “The Foreign Policy Orientations of Central Asian States: Positive and Negative Diversification", in "Eager Eyes Fixed on Eurasia - Russia and Its Neighbors in Crisis", ed. Iwashita Akihiro, 21st Century COE Program Slavic Eurasian Studies, No.16-1, 23-40.

Trenin, D. (2003a) "Pirouettes and Priorities: Distilling a Putin Doctrine", National Interest, Winter 2003,http://findarticles.com/p/articles/mi_m2751/is_74/ai_112411721/

Turkkazak, (2012), "Özbekistan İkinci Kez ŞïÖ Tatbikatına Kätılacak Kazak Asker ve Askeri Teçhizatın Topraklarından Geçmesine İzin Vermedi”, 21 September, http://turkkazak.com/site/?p=26263

Wilhelmsen, J. \&Flikke, G. (2011), "Chinese-Russian Convergence and Central Asia", Geopolitics, 16, 865-901.

World Population Review, Population of Uzbekistan 2013, (2013), http://worldpopulationreview.com/population-of-uzbekistan/

Yakushik, V.M. (2009), "The Influence of Afghanistan on Russian Foreign Policy Toward Central Asia After September 11, 2011”, НАУКОВІ ЗАПИСКИ, Том 95, Політичнінауки.

\title{
Summary \\ Ups and Downs in Foreign Policy of Uzbekistan towards Security Approach of Russia*
}

\author{
TugceVarolSevim \\ Moscow State University, Russia
}

\author{
Alexander Rozanov \\ Moscow State University, Russia
}

Uzbekistan is one of the significant states of Central Asia considering its relatively high population and military strength in comparison with other Central Asian states. We should not forget the fact that Uzbekistan has the most combat-ready and well-equipped armed forces in the region that have direct military experience in special operations in the mountains. Given this fact and the presence of a large Uzbek diaspora in neighboring countries, it is easy enough to understand why Tashkent pursues an independent policy and strives for leadership in Central Asia. However, the permanent President of the Republic of Uzbekistan Islam Karimov failed to achieve regional leadershipdue to on domestic political and economic reasons. But he was able to solve a number of major policy objectives: to achieve political stability, to suppress the influence of Islamists, to provide external security of Uzbekistan and to hold inter-clan balance. Although Uzbekistan, like other Central Asian 
nations, is a landlocked country, it has no direct border with the Russian Federation and China. Instead,Uzbekistan has border with Afghanistan and with its strategic location Uzbekistan will have a substantial role to play in the future of Central Asia. Nevertheless, Uzbekistan's foreign policy had displayed ups and downs concerning the security and economic regionalization of Kremlin's foreign policy strategies. In the summer of 2012, Uzbekistan suspended its membership in CSTO, which was the forthcoming main security organization of the Eurasia and even blocked the passage of Kazakh military vehicles from its territory for the SCO exercises in Tajikistan. Furthermore, Uzbekistan perceives that fundamental Islamic movements are a threat to its security and future. On the other hand, Uzbek leadership is waiting for the possible geopolitical changes in a region due to NATO's withdrawal from Afghanistan in 2014. This paper seeks to analyze the factors behind Uzbekistan's recent foreign policy activities and conclusions.

Keywords: Central Asia, Security, Uzbekistan, Russia, Afghanistan 